\title{
Development of Enzymatic - Colorimetric Time - Temperature Integrator for Smart Packaging
}

\author{
Caroline Fátima Casanova ${ }^{1 \mathbb{D}}$, Marina Andreia de Souza ${ }^{1 \mathbb{D}}$, Bruno Fischer ${ }^{1}{ }^{\mathbb{D}}$, Rosicler Colet ${ }^{1 \mathbb{D}}$, \\ Cristiane Michele Marchesi ${ }^{1}$ (D), Jamile Zeni 1,*(D), Rogério Marcos Dallago 1(D), Natalia Paroul 1(D), \\ Rogério Luis Cansian ${ }^{1}$ (D), Geciane Toniazzo Backes ${ }^{1}$ (D) \\ 1 Department of Food Engineering, URI - Erechim, Av.7 de Setembro, 1621, CEP 99709-910, Erechim, RS, Brazil; \\ carolinecasanova@hotmail.com (C.F.C.); mariina.2010@ hotmail.com (M.A.S.); bruno.fischer.com@ hotmail.com (B.F.); \\ rosicler.colet@yahoo.com.br (R.C.); cmarchesi@auroraalimentos.com.br (C.M.M.); jamilezeni@uricer.edu.br (J.Z.); \\ dallago@uricer.edu.br (R.M.D.); nparoul@uricer.edu.br (N.P.); cansian@uricer.edu.br (R.L.C.); gtoniazzo@uricer.edu.br \\ (G.T.B.); \\ * Correspondence: jamilezeni@uricer.edu.br;
}

Scopus Author ID 35323468700

Received: 9.08.2020; Revised: 5.09.2020; Accepted: 7.09.2020; Published: 11.09.2020

\begin{abstract}
A new enzymatic-colorimetric time-temperature integrator (ECTTI) to evaluate temperature abuse in refrigerated products was developed with Tributyrin, $\mathrm{pH}$ indicator, and lipase Calb. The kinetic behavior of the ECTTI $\left(0.01 \mu \mathrm{L} . \mathrm{L}^{-1}\right.$ enzyme $)$ was assessed at $5,10,15,20$, and $25^{\circ} \mathrm{C}$, evaluating changes in $\mathrm{pH}(\leq 7.2)$ and color $(\Delta \mathrm{E} \geq 12)$. Storage at $5^{\circ} \mathrm{C}$ provided stability of the enzyme indicator for 16 days, and temperature abuses caused stability reduction to $15,10,0.50 .3$ days, with $10,15,20$, and $25^{\circ} \mathrm{C}$ of storage, respectively. The sequential abuse of temperature stability of ECTTI was assessed by exposure at $5.0^{\circ} \mathrm{C}$ for $2 \mathrm{~h}$ and $25^{\circ} \mathrm{C}$ for 1 or $5 \mathrm{~min}$, returning to $5.0^{\circ} \mathrm{C}$ for another $2 \mathrm{~h}$, until the change in $\mathrm{pH}$ and color. The ECTTI subjected to temperature abuses for 5 and $1 \mathrm{~min} / 25^{\circ} \mathrm{C}$, remained stable for 5 and 9 cycles, respectively. The results of ECTTI stability before application, obtained with separate buffer/enzyme/water + substrate/indicator solutions, stored at 5 or $25^{\circ} \mathrm{C}$, before the reactive mixing of solutions, kept their stability, demonstrating the possibility of use as a tool against the temperature abuse conditions.
\end{abstract}

Keywords: Refrigeration; Microorganisms; Temperature Abuse; Food preservation; Chicken.

(C) 2020 by the authors. This article is an open-access article distributed under the terms and conditions of the Creative Commons Attribution (CC BY) license (https://creativecommons.org/licenses/by/4.0/).

\section{Introduction}

The quality and safety of chilled foods are strongly influenced by temperature, requiring monitoring throughout the distribution chain [1-3]. Unexpected changes or abuses in temperature in the cold food chain can compromise food safety and quality, which can result in loss of consumer confidence and increased levels of food waste [4]. Temperature abuse occurs when food is stored at temperatures that exceed the safe storage limit $\left(5^{\circ} \mathrm{C}\right)$ [5]. This type of temperature abuse usually occurs during product distribution, retail display, or domestic storage, when products in transit or storage are refrigerated under sub-optimal conditions [68].

The development of smart packaging with specific devices that allow the monitoring of the conditions of packaged products is becoming increasingly popular in response to the demand for high quality and food safety [9-12]. Different indicator systems such as temperature and time [13], gas sensors [14], $\mathrm{pH}$ [10], biosensors [15-17], and miniaturized biosensors [18] 
can provide qualitative information and quantitative in real-time, through color changes, incorporating them into the packaging material $[11,19]$.

The time and temperature indicators (TTI) are based on irreversible changes that can be physical, chemical, or biological [19-21]. The rate of this change depends on time and temperature, providing a cumulative indication of the storage conditions to which the product has been exposed [22]. The performance of the TTI system in monitoring food spoilage at both temperatures used in storage distribution has been studied for kimchi [23], frozen vegetables [24,25], fish products [26-28], meat products [26-31], mushrooms [32], dairy products [33,34], fresh food [35].

There are different types of TTIs on the market, enzymatic, microbiological, diffusion, polymeric, and photochemical [36]. Enzymatic TTIs are based on enzyme chemistry and have many benefits over other types of TTIs due to unwavering performance, low production cost, and easy control. An enzymatic TTI enables the development of a TTI with various activation energy values, as it can be used by conjoining different enzymes and substrates. Thus, it has the advantage of being applied as a tailored type of TTI for various food products undergoing a lot of quality changes during the supply chain. Its working principle is to produce an acid/base by enzymatic hydrolysis to increase or decrease $\mathrm{pH}$ value and then to dynamically display the cumulative effect of time and temperature by color changes of an acid-base indicator. The system can be calibrated to match the rate of spoilage of a designate product by altering several parameters: enzyme type and concentration, substrate type and concentration, $\mathrm{pH}$, and presence of a buffer [9]. Lipase based TTI shows an irreversible color change induced by a $\mathrm{pH}$ decline resulting from the controlled enzymatic hydrolysis of a lipid substrate, for example, tributyrin.

However, the literature still lacks results showing TTIs with similar durability to refrigerated food products when stored correctly, that allows handling of the packaging with removal from the refrigeration gondola for short periods of time, and with stability before being placed in contact with the product. In this context, the objective of this work was to develop a colorimetric enzyme system of time and temperature, with stability similar to that of chilled raw meat products, that allow product manipulations in market shelves and with stability prior to its application in the product packaging, in view of food security due to the negligence of some establishments regarding the lack of temperature control in refrigerated food gondolas.

\section{Materials and Methods}

\subsection{Development of the enzymatic indicator.}

The preparation of the colorimetric enzyme indicator was carried out with a commercially available enzyme, lipase Calb L Novozym (batch LCN 02115), with the declared activity of $5000 \mathrm{LU}_{\mathrm{g}}{ }^{-1}$. The reactional system of the time and temperature indicator was composed of $4 \mathrm{mM}$ Tributiryn, $0.1 \%$ Triton X-100, $2.5 \%$ buffer $\left(\mathrm{Na}_{2} \mathrm{HPO}_{4} 0.2 \mathrm{mM}\right.$, citric acid $0.1 \mathrm{mM}, \mathrm{pH} 7.5$ ), $8.5 \% \mathrm{pH}$ indicator (mixture of $0.1 \%$ bromothymol blue, methyl red, neutral red, 12:4:1) [37] varying the enzyme concentration $(20000 ; 15000 ; 10000 ; 5000 ; 1000$; $500 ; 100 ; 250 ; 1 ; 0.1 ; 0.05 ; 0.01$ e $\left.0.005 \mu \mathrm{L} \mathrm{L}^{-1}\right)$. The $\mathrm{pH}$ indicator led to an irreversible color change from green to orange and finally to red (the endpoint), indicating a progressive decline from $\mathrm{pH} 8.0$ to 6.0. The experiments were carried out, exposing the reaction system in controlled temperature conditions to 5 and $25^{\circ} \mathrm{C}$ (temperature abuse), determining the $\mathrm{pH}$ and $\Delta \mathrm{E}$ of each sample every $6 \mathrm{~h}$. 
In carrying out experiments to define the concentration of enzyme to be used in the colorimetric system, it was observed that the color rapidly altered when exposed to room temperature (around $25^{\circ} \mathrm{C}$ ) at the time of the analyzes. Thus, was evaluated the influence of temperature fluctuations when reading the $\mathrm{pH}$ of the reaction system, exposing the colorimetric system to room temperature $\left(25.0^{\circ} \mathrm{C} \pm 2.0\right)$ with and without bath ice for up to $5 \mathrm{~min}$, for the reading of $\mathrm{pH}$.

$\mathrm{pH}$ values were determined using a digital $\mathrm{pH}$ meter (Digimed DMPH-2). The chromaticity change ( $\Delta \mathrm{E}$ value) was measured using $\mathrm{CIE}$ Lab color space coordinates to objectively describe the irreversible TTI color change per unit time at different constant temperatures, and the $\Delta \mathrm{E}$ value was expressed by the following Equation 1.

$$
\llbracket \Delta \mathrm{E} \rrbracket \wedge=\sqrt{ }\left((\llbracket \Delta \mathrm{L} \rrbracket \wedge(*))^{\wedge} 2+(\llbracket \Delta \mathrm{a} \rrbracket \wedge(*))^{\wedge} 2+(\llbracket \Delta \mathrm{b} \rrbracket \wedge(*))^{\wedge} 2\right)
$$

Where $\mathrm{L}^{*}$ is the difference in brightness (white-black) change between $\mathrm{t}=0$ and measured unit time; $a^{*}$ is the difference in redness-greenness, and $b^{*}$ is the difference in yellowness-blueness [38].

\subsection{Effect of temperature on the kinetic behavior of the indicator.}

The kinetic behavior of colorimetric enzymatic indicator of time and temperature was evaluated, keeping the enzyme concentration of $0.01 \mu \mathrm{L} . \mathrm{L}^{-1}$ and exposing the reaction system to different temperatures $\left(5,10,15,20\right.$, and $\left.25^{\circ} \mathrm{C}\right)$. For each temperature tested, the final samples' follow-up time was determined by change in $\mathrm{pH}$ and color. During the period of exposure to $25^{\circ} \mathrm{C}$, the reactive system was kept in contact with a bath ice base.

\subsection{Evaluation of the stability of the reaction system.}

To evaluate the stability of the reactive system to small temperature fluctuations, a condition of handling the food packaging by the consumers was simulated in the choose the product during the day and also without manipulation, during the night. For that, a test was carried out, submitting the reactive system to cooling $\left(5.0^{\circ} \mathrm{C} \pm 1.0\right)$ for $2 \mathrm{~h}$ and then exposed to $25^{\circ} \mathrm{C}$ for 1 and $5 \mathrm{~min}$ and then returned to $5.0^{\circ} \mathrm{C}$ for another $2 \mathrm{~h}$ (simulating manipulation during the day). During the exposure to $25^{\circ} \mathrm{C}$, the reactive system was kept in contact with a cold base (gel ice -Techgel), to simulate a refrigerated product in contact with the reactive system package. During the night, this system was kept under constant refrigeration $\left(5.0^{\circ} \mathrm{C} \pm 1.0\right)$. The reactive system was monitored to changes $\mathrm{pH}$ and color, evaluating stability at different cycles of 1 and $5 \mathrm{~min}$ at $25^{\circ} \mathrm{C}$.

\subsection{Evaluation of the reactional stability of the solutions that make up the indicator.}

Aiming at the practical applicability of the developed reaction system, the conservation of the in separated solutions was studied, since, when all the relational components are mixed, the color and $\mathrm{pH}$ change process can already be started. This study is important because, during the filling of the products, the packaging can go through the process of thermo shrinkage and vacuum sealing, which causes an increase in temperature and thus could trigger the reaction system. For this, the conservation at different temperatures $\left(5\right.$ and $\left.25^{\circ} \mathrm{C}\right)$ of two different solutions was studied, aim to evaluate the need to preserve the reaction components under refrigeration or ambient temperature. The reaction systems I (buffer/enzyme/water + substrate/indicator) and II (buffer/enzyme/indicator/water + substrate) with the groups of 
compounds still separated, were maintained at 5 and $25^{\circ} \mathrm{C}$ for $24 \mathrm{~h}$, with subsequent mixing between the groups of reaction components of each system. All the reaction systems were evaluated by determining the $\mathrm{pH}$ and color, with temperature abuse at $25^{\circ} \mathrm{C}$.

\subsection{Statistical analysis.}

All analyzes were performed in triplicate, and graphs and linear regression were performed using the Excel software.

\section{Results and Discussion}

\subsection{Development of the enzymatic indicator.}

A time-temperature indicator must provide an answer that is understandable, perceptible, and easy to read by consumers [39]. In this sense, a reactive system of easy responses was developed, where after the addition of the enzyme in the indicator, a color change can be observed in the $\mathrm{pH}$ variation functions by hydrolysis of the taxed substrate in case of temperature abuse (Fig. 1).

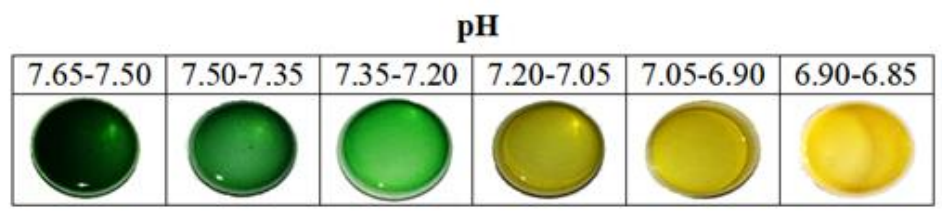

Figure 1. The color variation of the enzymatic indicator of time-temperature in relation to the reduction of $\mathrm{pH}$.

The results related to the colorimetric enzymatic system developed with different concentrations of enzyme and exposed to 5 and $25^{\circ} \mathrm{C}$, showed that the enzymatic indicator with the same concentration of enzyme, when exposed to different temperature conditions, results in different stability times. It is worth noting that the higher the exposure temperature of the enzymatic indicator, the faster the $\mathrm{pH}$ reduction and the consequent color change occurs in any of the enzyme concentrations evaluated. This phenomenon was also observed by Wu et al. [40], who developed an enzymatic time-temperature indicator using lipase from Aspergillus niger.

When analyzing or behavior of the enzyme indicator in relation to the enzyme concentration, it was observed that the system containing $20000 \mu \mathrm{L} . \mathrm{L}^{-1}$ of enzymes changed the $\mathrm{pH}$ from 7.80 to 5.27 and the visual aspect (green to medium yellow) in $3 \mathrm{~h}$. While with $0.01 \mu \mathrm{L} . \mathrm{L}^{-1}$ it remains stable for 9 days, with no color change and without significant reduction in $\mathrm{pH}(7.75-7.21)$, when maintained at $5^{\circ} \mathrm{C}$. The lowest concentration of the enzyme studied $\left(0.005 \mu \mathrm{L} . \mathrm{L}^{-1}\right)$ was insufficient to promote the tributyrin hydrolysis reaction and consequent reduction in $\mathrm{pH}$ and color change. Thus, the enzyme concentration defined for the subsequent steps was $0.01 \mu \mathrm{L} . \mathrm{L}^{-1}$.

According to Jaiswal et al. [41], the use of lipases for the development of timetemperature indicators is economically viable and can be considered of great commercial value, as these enzymes catalyze various reactions in liquefied and non-liquefied states. In addition to presenting high catalytic activity, such as the Calb lipase used in the present work, which allowed the efficiency of the reaction system in small quantities.

Regarding the stability of the reactive system to small temperature fluctuations, maintaining the enzymatic reaction system in an ice bath during $\mathrm{pH}$ determination, it was possible to minimize the influence of temperature fluctuation, keeping it stable for 18 days with 
a pH above 7.20. The samples kept without an ice bath presented a $\mathrm{pH}$ of 5.9 at 18 days. This result demonstrates that the exposure of the reaction system to temperature variations, even for a short time, causes a cumulative and irreversible effect on the reaction result (color change from green to yellow).

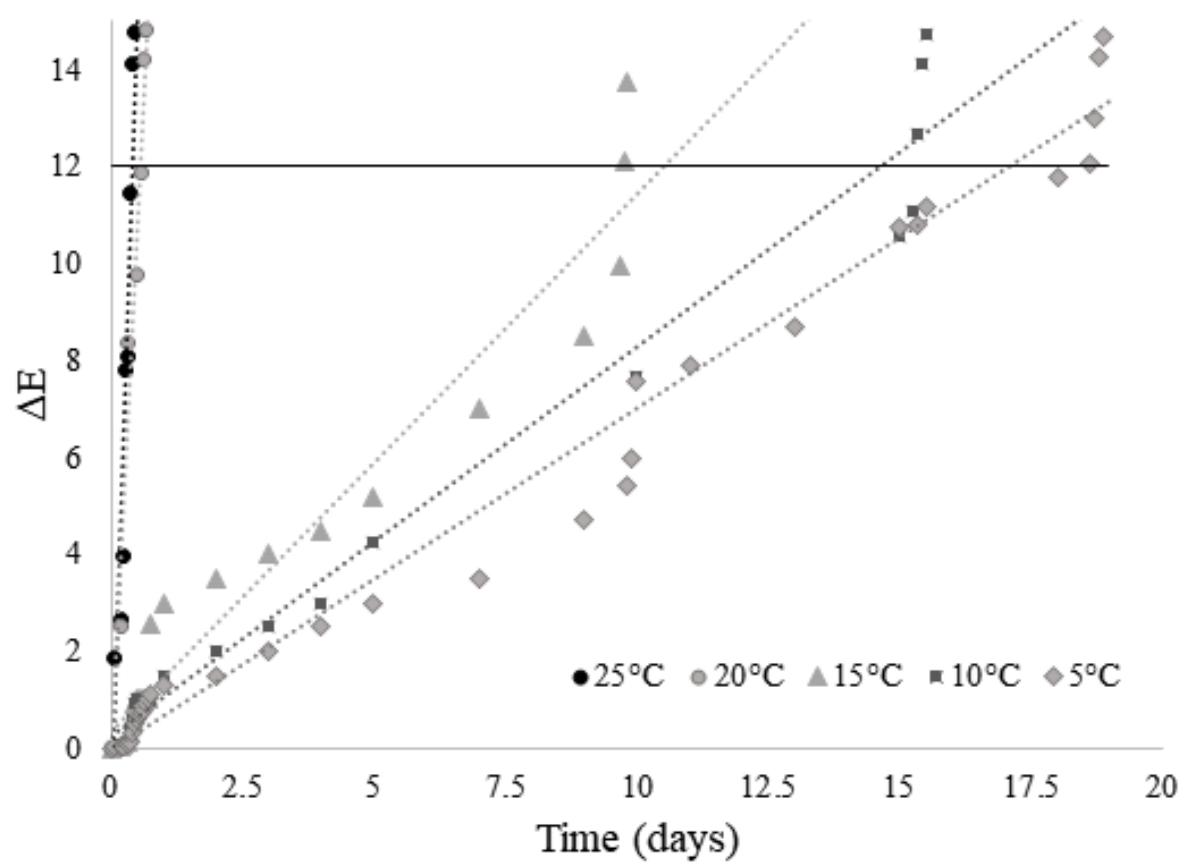

(a)

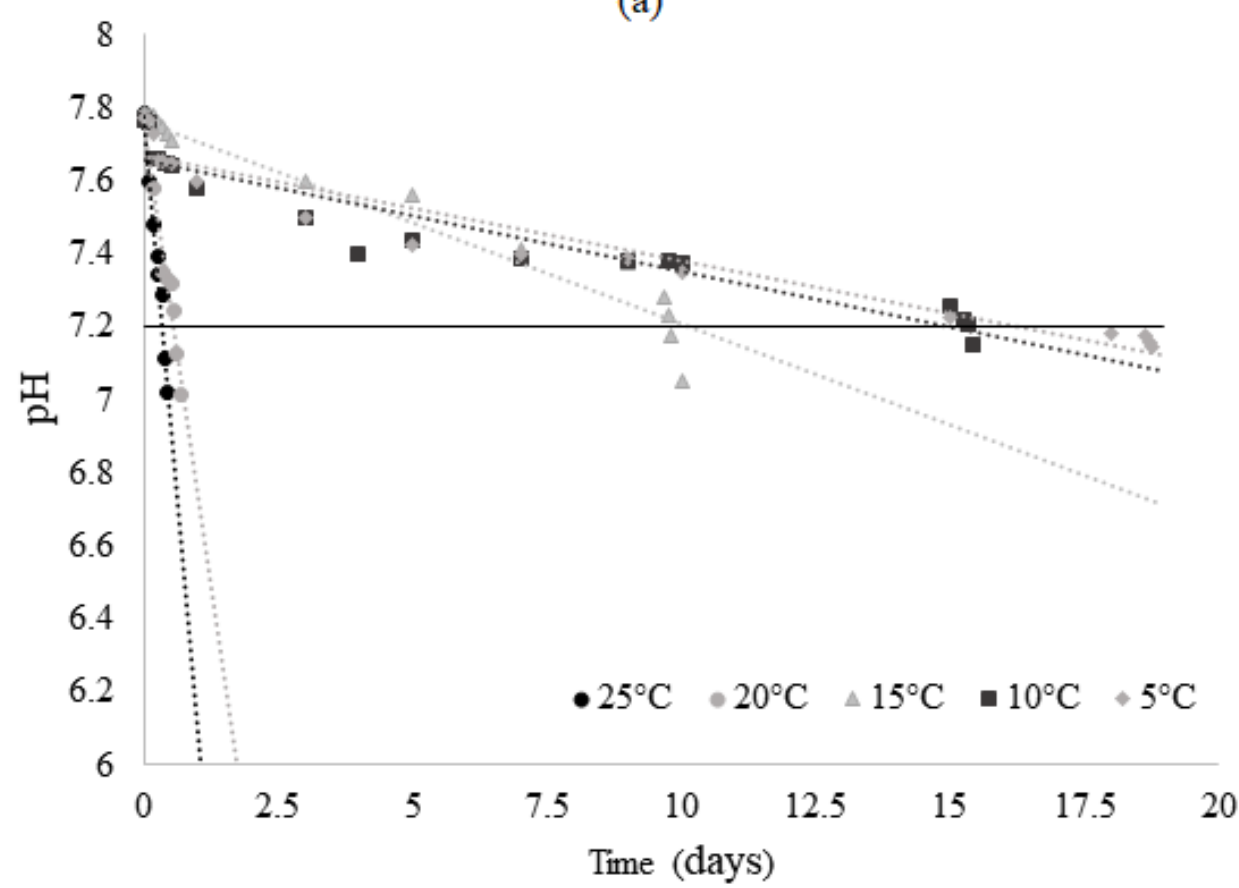

(b)

Figure 2. Kinetic behavior of the time-temperature indicator as a function of $\Delta \mathrm{E}$ (a) e $\mathrm{pH}$ (b) subjected to different temperatures. Where $\Delta \mathrm{E}=12.0$ and $\mathrm{pH}$ de 7.2 refer to the perceived color change by consumers.

\subsection{Influence of temperature on the color of the enzymatic indicator.}

After defining the enzyme concentration $\left(0.01 \mu \mathrm{L} . \mathrm{L}^{-1}\right)$ and conditions for evaluating the enzymatic indicator (ice bath), it was stored at different temperatures, 5, 10, 15, 20, and 
$25^{\circ} \mathrm{C}$, to determine the behavior kinetic through changes in the $\Delta \mathrm{E}$ value and $\mathrm{pH}$ as a function of temperature (Fig. 2). The temperature values studied represent the conditions used in the chilled product distribution chain, from the producer to the final consumer [42-44].

In Fig. $2 \mathrm{a}, \Delta \mathrm{E}=12.0$ refers to the perceived color change by consumers. A progressive reduction in the time of color change can be observed with the increase of the storage temperature and a drastic reduction of this time in storage with temperature abuse (20 and $25^{\circ} \mathrm{C}$ ). In Fig. $2 \mathrm{~b}, \mathrm{pH} 7.2$ indicates the limit of $\mathrm{pH}$ variation for maintaining the green color. Slow $\mathrm{pH}$ reduction at lower storage temperatures and rapid reduction when stored in 20 and $25^{\circ} \mathrm{C}$ are identified.

From the kinetics of $\Delta \mathrm{E}$ and $\mathrm{pH}$ presented in Fig. $2 \mathrm{a}$ and $2 \mathrm{~b}$, the equations for each temperature were obtained, and these are used to determine the validity time of the indicator at each temperature when the $\Delta \mathrm{E}$ reaches 12.0 and $\mathrm{pH} 7.2$ (Table 1).

There is a linear behavior of $\mathrm{pH}$ reduction and an increase in color variation $\Delta \mathrm{E}$ (green to yellow) in relation to the storage time for all evaluated temperatures. Storage at $5^{\circ} \mathrm{C}$ caused stability of the enzyme indicator for 16.33 days in relation to the minimum $\mathrm{pH}$ (7.2) and 17.02 days in relation to the noticeable color variation $(\Delta \mathrm{E}=12.0)$. These results indicate that it could be used for products with a shelf-life of up to 16 days and that temperature abuses would reduce this shelf-life to up to 0.3 days, demonstrated by the enzymatic indicator when submitted to $25^{\circ} \mathrm{C}$.

Kim et al. [37], evaluating the development of the enzyme time-temperature indicator with lipase from Burkholderia cepacia observed lower reaction stability when evaluating different exposure temperatures. These authors obtained times from 0.4 days to $26^{\circ} \mathrm{C}, 0.67$ days to $20^{\circ} \mathrm{C}, 1.1$ days to $15^{\circ} \mathrm{C}, 2.0$ days to $10^{\circ} \mathrm{C}$, and 3.8 days to $5^{\circ} \mathrm{C}$ to reach the final color change point, stability times lower than obtained in the present work.

Table 1. Validity time of the temperature indicator when $\Delta \mathrm{E}=12.0$ and $\mathrm{pH}=7.2$

\begin{tabular}{|c|c|c|c|c|}
\hline \multirow{2}{*}{$\begin{array}{c}\text { Temperature } \\
\left({ }^{\circ} \mathbf{C}\right)\end{array}$} & \multicolumn{2}{|l|}{$\mathbf{p H}$} & \multicolumn{2}{|l|}{$\Delta \mathbf{E}$} \\
\hline & Equation & Time (days) & Equation & Time (days) \\
\hline 5 & $\begin{array}{c}\mathrm{y}=-0.0287 \mathrm{x}+7.6687 \\
\mathrm{R}^{2}=0.9348\end{array}$ & 16.33 & $\begin{array}{c}\mathrm{y}=0.7067 \mathrm{x}-0.0317 \\
\mathrm{R}^{2}=0.9794\end{array}$ & 17.02 \\
\hline 10 & $\begin{array}{c}y=-0.0304 x+7,6555 \\
R^{2}=0.9057\end{array}$ & 14.98 & $\begin{array}{c}\mathrm{y}=0.8054 \mathrm{x}+0.2375 \\
\mathrm{R}^{2}=0.977\end{array}$ & 14.60 \\
\hline 15 & $\begin{array}{c}y=-0.0554 x+7,7645 \\
R^{2}=0.9312\end{array}$ & 10.19 & $\begin{array}{c}\mathrm{y}=1.1115 \mathrm{x}+0.3207 \\
\mathrm{R}^{2}=0.9463\end{array}$ & 10.50 \\
\hline 20 & $\begin{array}{c}\mathrm{y}=-1.0138 \mathrm{x}+7.7605 \\
\mathrm{R}^{2}=0.9523\end{array}$ & 0.55 & $\begin{array}{c}\mathrm{y}=21.7 \mathrm{x}-0.1836 \\
\mathrm{R}^{2}=0.9781\end{array}$ & 0.56 \\
\hline 25 & $\begin{array}{c}y=-1.6676 x+7.7756 \\
R^{2}=0.9709\end{array}$ & 0.34 & $\begin{array}{c}\mathrm{y}=32.749 \mathrm{x}-1.4901 \\
\mathrm{R}^{2}=0.9429\end{array}$ & 0.41 \\
\hline
\end{tabular}

The $\Delta \mathrm{E}$ values (Table 1) obtained showed that there was a significant color change in the reaction systems with a gradual increase in temperature. This result must corroborate with the microbiological changes when exposing the samples of refrigerated products in the condition of temperature abuse [39], with different times of product's useful life at a different temperature of exposition.

\subsection{Evaluation of the stability of the reaction system to sequential abuse of temperature.}

Fig. 3 present the number of cycles obtained from exposing the reaction system to sequential temperature abuses, kept at room temperature $\left(25^{\circ} \mathrm{C}\right)$ for 1 or $5 \mathrm{~min}$ and subsequent return to refrigeration $\left(5^{\circ} \mathrm{C}\right)$ for $2 \mathrm{~h}$ to stabilize the temperature, simulating withdrawals and returns of the product to the gondola, until a change in $\mathrm{pH}(<7.2)$. The indicator subject to 
temperature abuse for 5 min remained stable for 5 cycles, whereas the indicator exposes to temperature abuse for 1 min remained stable for 9 cycles.

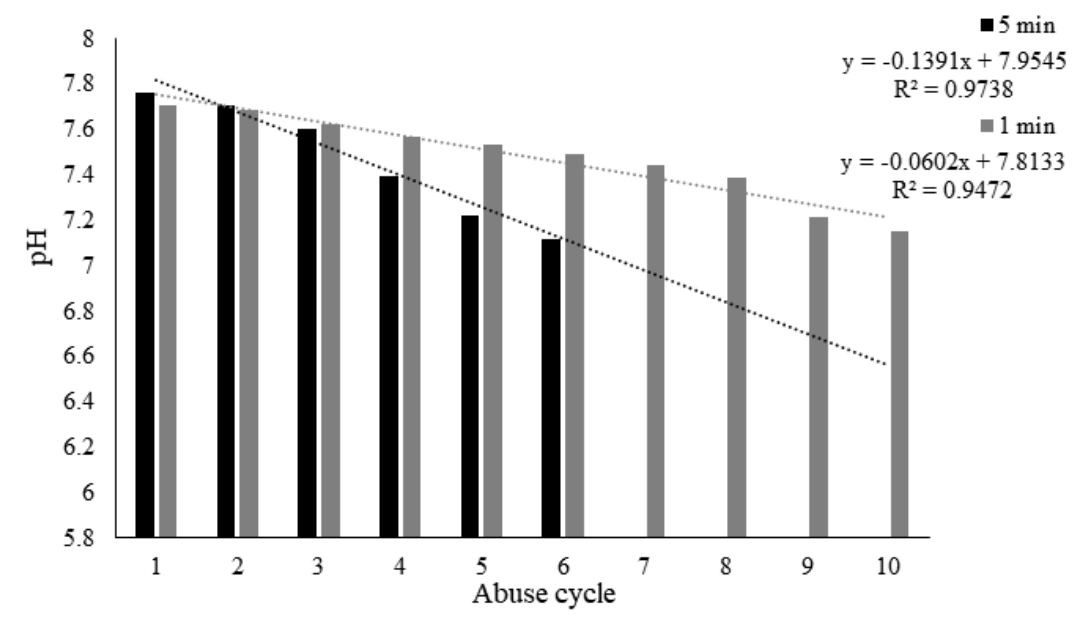

Figure 3. Sequential abuse cycles of the reaction system exposed to $25^{\circ} \mathrm{C}$ for 1 and 5 min and then returned to refrigeration for $2 \mathrm{~h}$.

\subsection{Evaluation of the reaction stability of the solutions that form the indicator.}

Time-temperature indicators are devices used on the surface of a package that undergoes color changes, for example, showing the accumulated history of temperature abuse of a food [20,45,50 ]. According to Mataragas et al. [5], TTI can be applicable to a wide range of methods, only promoting small adjustments in its parameters, taking into account the deterioration kinetics of the respective product, thus improving the management of the cold chain and reducing food waste.

Thus, it is interesting that the enzyme indicator associated with a package can be activated only after the products are stored $\left(<5.0^{\circ} \mathrm{C}\right)$ and can be maintained without starting the reaction before manipulation and temperature variation. In this sense, combinations of the reaction system I (buffer/enzyme/water + substrate/indicator) and II (buffer/enzyme/indicator/water + substrate) were monitored at 5 and $25^{\circ} \mathrm{C}$ in order to apply them to the packaging surfaces, with the homogenization of the groups of compounds after refrigeration.

From the kinetic monitoring of the 2 systems, it was possible to obtain the equations for each of these, which are used to determine the validity time of each indicator when it reaches the value of $\Delta \mathrm{E} 12.0$ and $\mathrm{pH} 7.2$ (Table 2).

Table 2. Validity time of systems I, II, III, and IV time-temperature indicators when $\Delta \mathrm{E}=12$ and $\mathrm{pH}=7.2$.

\begin{tabular}{|c|c|c|c|c|}
\hline \multirow{2}{*}{ Temperature $\left({ }^{\circ} \mathrm{C}\right)$} & \multicolumn{2}{|l|}{ pH } & \multicolumn{2}{|l|}{$\Delta \mathbf{E}$} \\
\hline & Equation & Time (days) & Equation & Time (days) \\
\hline $\begin{array}{c}\text { System I } \\
\left(5^{\circ} \mathrm{C}\right)\end{array}$ & $\begin{array}{c}\mathrm{y}=-0.0768 \mathrm{x}+7.8735 \\
\mathrm{R}^{2}=0.9765\end{array}$ & 0.41 & $\begin{array}{c}\mathrm{y}=1.2868 \mathrm{x}-0.6747 \\
\mathrm{R}^{2}=0.9848\end{array}$ & 0.41 \\
\hline $\begin{array}{c}\text { System II } \\
\left(5^{\circ} \mathrm{C}\right)\end{array}$ & $\begin{array}{c}\mathrm{y}=-0.011 \mathrm{x}+7.5671 \\
\mathrm{R}^{2}=0.6833\end{array}$ & 33.37 & $\begin{array}{c}\mathrm{y}=0.1415 \mathrm{x}+2.268 \\
\mathrm{R}^{2}=0.6312\end{array}$ & 68.78 \\
\hline $\begin{array}{l}\text { System I } \\
\left(25^{\circ} \mathrm{C}\right)\end{array}$ & $\begin{array}{c}y=-0.0563 x+7.753 \\
R^{2}=0.9765\end{array}$ & 0.41 & $\begin{array}{c}\mathrm{y}=1.2749 \mathrm{x}-0.3926 \\
\mathrm{R}^{2}=0.9788\end{array}$ & 0.40 \\
\hline $\begin{array}{c}\text { System II } \\
\left(25^{\circ} \mathrm{C}\right)\end{array}$ & $\begin{array}{c}y=-0.0096 x+7.6087 \\
R^{2}=0.8023\end{array}$ & 42.57 & $\begin{array}{c}\mathrm{y}=0.1243 \mathrm{x}+2.1304 \\
\mathrm{R}^{2}=0.6132\end{array}$ & 79.40 \\
\hline
\end{tabular}

The test results show the inefficiency of the enzymatic indicators for the systems where there was no homogenization of the substrate with the other components of the reaction (system II at both temperatures of storage), which caused the $\mathrm{pH}$ and color not to change. 
The results obtained for the system I had a reduction in $\mathrm{pH}$ and color change after 0.4 $\mathrm{h}$ at $25^{\circ} \mathrm{C}$. This result is due to the ease of mixing between the reagents (buffer/enzyme/water + substrate/indicator) stored at 5 or $25^{\circ} \mathrm{C}$ for $24 \mathrm{~h}$, mixed and submitted to temperature abuse $\left(25^{\circ} \mathrm{C}\right)$.

Thus, the enzymatic indicator developed (a system I) has the potential to be applied in the monitoring of temperature abuses in foods that receive refrigeration. In addition, this enzymatic indicator can be used as a tool to identify possible negligence of some establishment's regarding the lack of temperature control in refrigerated food expositors. Considering the microbiological risk associated with temperature abuses, this tool is of great importance throughout the distribution and storage chain of chilled products, aiming at food security.

\section{Conclusions}

The concentration of enzymes, temperatures influence, and the stability of the reaction system was studied to obtain an easy-to-read and stable time-temperature indicator for small temperature fluctuations after commercial application.

The colorimetric enzyme time-temperature indicator was developed with $0.01 \mu \mathrm{L} . \mathrm{L}^{-1}$ of the enzyme Calb L, remained stable for approximately 16 days, stored at $5^{\circ} \mathrm{C}$. The enzyme indicator allowed 9 and 5 cycles of product removal from the refrigerator and exposure to $25^{\circ} \mathrm{C}$, for 1 and $5 \mathrm{~min}$, respectively. The colorimetric enzymatic system divided into 2 groups of solutions (buffer/enzyme/water) and (substrate/indicator) can be maintained without starting the reaction, under refrigeration, or at $25^{\circ} \mathrm{C}$. After homogenization of the solution and $25^{\circ} \mathrm{C}$, $\mathrm{pH}$ and color changes in $9 \mathrm{~h}$ ( 0.4 days).

\section{Funding}

This research received no external funding.

\section{Acknowledgments}

This study was financed in part by the National Council for Scientific and Technological Development - Brazil (CNPq), Coordination for the Improvement of Higher Education Personnel - Brazil (CAPES) - Finance Code 001, and Research Support Foundation of the State of Rio Grande of Sul - Brazil (FAPERGS).

\section{Conflicts of Interest}

The authors declare no conflict of interest.

\section{References}

1. Man, C.M.D. Development of a predictive model for spoilage of cooked cured meat products and its validation under constant and dynamic temperature storage conditions. Food Sci. 2016, 71, 157-167, https://doi.org/10.1111/j.1750-3841.2006.00058.x.

2. Rahman, U.; Sahar, A.; Ishaq, A.; Aadil, R.M.; Zahoor, T.; Ahmad, M.H. Advanced meat preservation methods: A mini review. J. Food Saf. 2018, 38, https://doi.org/10.1111/jfs.12467.

3. Wu, J-Y.; Hsiao, H-I. Food quality and safety risk diagnosis in the food cold chain through failure mode and effect analysis. Food Control. 2021, 120, 107501, https://doi.org/10.1016/j.foodcont.2020.107501.

4. Ndraha, N.; Hsiao, H.-I.; Vlajic, J.; Yang, M.-F.; Lin, V.H.-T. Time-temperature abuse in the food cold chain: Review of issues, challenges, and recommendations. Food Control 2018, 89, 12-21, https://doi.org/10.1016/j.foodcont.2018.01.027. 
5. Mataragas, M.; Bikouli, V.C.; Korre, M.; Sterioti, A.; Skandamis, P.N.; Development of a microbial Time Temperature Indicator for monitoring the shelf life of meat, Innov. Food Sci. Emerg. Technol. 2019, 52, 8999, https://doi.org/10.1016/j.ifset.2018.11.003.

6. Jol, S.; Kassianenko, A.; Wszol, K.; Oggel, J. Issues in time and temperature abuse of refrigerated foods. Food Safety Mag. 2006, 30-32.

7. Zeng, W.; Vorst, K.; Brown, W.; Marks, B.P.; Jeong, S.; Pérez-Rodríguez, F.; Ryser, E.T. Growth of Escherichia coli O157:H7 and Listeria monocytogenes in packaged fresh-cut romaine mix at fluctuating temperatures during commercial transport, retail storage, and display. J. Food Prot. 2014, 77, 197-206, https://doi.org/10.4315/0362-028X.JFP-13-117.

8. Huang, J.; Luo, Y.; Zhou, B.; Zheng, J.; Nou, X. Growth and survival of Salmonella enterica and Listeria monocytogenes on fresh-cut produce and their juice extracts: Impacts and interactions of food matrices and temperature abuse conditions. Food Control 2019, 100, 300-304, https://doi.org/10.1016/j.foodcont.2018.12.035.

9. Brizio, A.P.D.R.; Prentice, C. Development of an intelligent enzyme indicator for dynamic monitoring of the shelf-life of food products. Innov. Food Sci. Emerg. Technol. 2015a, 30, 208-217, https://doi.org/10.1016/j.ifset.2015.04.001.

10. Pourjavaher, S.; Almasi, H.; Meshkini, S.; Pirsa, S.; Parandi, E. Development of a colorimetric pH indicator based on bacterial cellulose nanofibers and red cabbage (Brassica oleraceae) extract. Carbohydr. Polym. 2017, 156, 193-201, https://doi.org/10.1016/j.carbpol.2016.09.027.

11. Maftoonazad, N.; Ramaswamy, H. Design and testing of an electrospun nanofiber at as a pH biosensor and monitor the $\mathrm{pH}$ associated quality in fresh date fruit (Rutab). Polymer Testing. 2019, 75, 76-84, https://doi.org/10.1016/j.polymertesting.2019.01.011.

12. Kuntzler, G.S.; Costa, A.V.J.; Brizio, P.D.R.A.; Morais, G.M. Development of a colorimetric pH indicator using nanofibers containing Spirulina sp. LEB 18. Food Chem. 2020, 328, https://doi.org/10.1016/j.foodchem.2020.126768.

13. Brizio, A.P.D.R.; Prentice, C. Development of Aa New Time Temperature Indicator for Enzymatic Validation of Pasteurization of Meat Products. J. Food Sci. 2015b, 80, 1271-1276, https://doi.org/10.1111/1750-3841.12889.

14. Hussain, M.M.; Asiri, A.M.; Arshad, M.N.; Rahman, M.M. Development of selective Co2+ ionic sensor based on various derivatives of benzenesulfonohydrazide (BSH) compound: An electrochemical approach. Chem. Eng. J. 2018, 339, 133-143, https://doi.org/10.1016/j.cej.2018.01.130.

15. Kerry, J.; O'grady, M.; Hogan, S. Past, current and potential utilization of active and intelligent packaging systems for meat and muscle-based products: A review. Meat Sci. 2006, 74, 113-130, https://doi.org/10.1016/j.meatsci.2006.04.024.

16. Riu, J.; Giussani, B. Electrochemical biosensors for the detection of pathogenic bacteria in food. Trend. Anal. Chem. 2020, 126, 115863, https://doi.org/10.1016/j.trac.2020.115863.

17. Griesche, C.; Baeumner, A.J.; Biosensors to support sustainable agriculture and food safety. Trend. Anal. Chem. 2020, 128, 115906, https://doi.org/10.1016/j.trac.2020.115906.

18. Liu D.; Wang, J.; Wu, L.; Huang, Y.; Zhang, Y.; Zhu, M.; Wang, Y.; Zhu, Z.; Yang, C. Trends in miniaturized biosensors for point-of-care testing. Trend. Anal. Chem. 2020, 122, 115701, https://doi.org/10.1016/j.trac.2019.115701.

19. Brody, A.L.; Bugusu, B.; Han, J.H.; Sand, C.K.; McHugh, T.H. Scientific Status Summary. J. Food Sci. 2008, 73, 107-116, https://doi.org/10.1111/j.1750-3841.2008.00933.x.

20. Mai, N.T.T.; Gudjónsdóttir, M.; Lauzon, H.L.; Sveinsdóttir, K.; Martinsdóttir, E.; Audorff, H.; Reichstein, W.; Haarer, D.; Bogason, S.G.; Arason, S. Continuous quality and shelf life monitoring of retail-packed fresh cod loins in comparison with conventional methods. Food Control 2011, 22, 1000-1007, https://doi.org/10.1016/j.foodcont.2010.12.010.

21. Yoshida, C.M.; Maciel, V.B.V.; Mendonça, M.E.D.; Franco, T.T. Chitosan biobased and intelligent films: monitoring $\mathrm{pH}$ variations. LWT-Food Sci. Technol. 2014, 55, 83-89, https://doi.org/10.1016/j.lwt.2013.09.015.

22. Kreyenschmidt, J.; Christiansen, H.; Hübner, A.; Raab, V.; Petersen, B. A novel photochromic timetemperature indicator to support cold chain management. Int. J. Food Sci. Technol. 2010, 45, 208-215, https://doi.org/10.1111/j.1365-2621.2009.02123.x.

23. Veiga-Santos, P.; Ditchfield, C.; Tadini, C. Development and evaluation of a novel pH indicator biodegradable film based on cassava starch. J. Appl. Polym. Sci. 2011, 120, 1069-1079, https://doi.org/10.1002/app.33255.

24. Almeida, M.I.G.; Estela, J.M.; Segundo, M.A.; Cerdà, V.A. Membraneless gas-diffusion unit-multisyringe flow injection spectrophotometric method for ammonium determination in untreated environmental samples. Talanta. 2011, 84, 1244-1252, https://doi.org/10.1016/j.talanta.2010.12.052.

25. Kato, E.T.; Yoshida, C.M.; Reis, A.B.; Melo, I.S.; Franco, T.T. Fast detection of hydrogen sulfide using a biodegradable colorimetric indicator system. Int. J. Polym. 2011, 60, 951-956, https://doi.org/10.1002/pi.3095.

26. Devarayan, K.; Kim, B.S. Reversible and universal pH sensing cellulose nanofibers for health monitor. Sens. 
Actuators B Chem. 2015, 209, 281-286, https://doi.org/10.1016/j.snb.2014.11.120.

27. Mishra, A.K.; Mishra, S.B.; Tiwari, A. Nanocomposites and Their Biosensor Applications. Wiley-VCH Verlag, Weinheim, Germany, 2011; 255-268, https://doi.org/10.3390/chemosensors3020169.

28. Chandrasekhar, J.; Madhusudhan, M.; Raghavarao, K. Extraction of anthocyanins from red cabbage and purification using adsorption. Food Bioprod. Proces. 2012, 90, 615-623, https://doi.org/10.1016/j.fbp.2012.07.004.

29. Janik, L.; Cozzolino, D.; Dambergs, R.; Cynkar, W.; Gishen, M. The prediction of total anthocyanin concentration in red-grape homogenates using visible-near-infrared spectroscopy and artificial neural networks. Anal. Chim. Acta. 2007, 594, 107-118, https://doi.org/10.1016/j.aca.2007.05.019.

30. Castañeda-ovando, A.; Pacheco-Hernández, M.D.L.; Páez-Hernández, M.E.; Rodríguez, J.A.; Galán-Vidal, C.A. Chemical studies of anthocyanins: a review. Food Chem. 2009, 113, 859-871, https://doi.org/10.1016/j.foodchem.2008.09.001.

31. Pacquit, A.; Frisby, J.; Diamond, D.; Lau, K.T.; Farrell, A.; Quilty, B.; Diamond, D. Quilty, B. Diamond, D. Development of a smart packaging for the monitoring of fish spoilage. Food Chem. 2007, 102, 466-470, https://doi.org/10.1016/j.foodchem.2006.05.052.

32. Maciel, V.B.V.; Yoshida, C.M.; Franco, T.T. Chitosan/pectin polyelectrolyte complex as a pH indicator.Carbohydrate Polymer. 2015, 132, 537-545. https://doi.org/10.1016/j.carbpol.2015.06.047.

33. Aceituno-Medina, M.; Lopez-Rubio, A.; Mendoza, S.; Lagaron, J.M. Development of novel ultrathin structures based in amaranth (Amaranthus hypochondriacus) protein isolate through electrospinning. Food Hydrocolloid. 2013, 31, 289-298, https://doi.org/10.1016/j.foodhyd.2012.11.009.

34. Deng, L.; Zhang, X.; Li, Y.; Que, F.; Kang, X.; Liu, Y.; Feng, F.; Zhang, H. Characterization of gelatin/zein nanofibers by hybrid electrospinning. Food Hydrocolloid. 2018, 75, 72-80. https://doi.org/10.1016/j.foodhyd.2017.09.011.

35. Gao, T.; Tian, Y.; Zhu, Z., Sun, D-W. Modelling, responses and applications of time-temperature indicators (TTIs) in monitoring fresh food quality. Trend. Food Sci. Technol. 2020, 99, 311-322, https://doi.org/10.1016/j.tifs.2020.02.019.

36. Jhuang, J-R.; Lou, S-N.; Lin, S-B.; Chen, S.H.; Chen, L-C.; Chen, H-H. Immobilizing laccase on electrospun chitosan fiber to prepare time-temperature indicator for food quality monitoring. Innov. Food Sci. Emerg. Technol. 2020, 63, 102370, https://doi.org/10.1016/j.ifset.2020.102370

37. Kim, W.; Park, E.; Hong, K. Development of a time-temperature integrator system using Burkholderia cepacia lipase. Food Sci. Biotechnol. 2012, 21, 497-502, https://doi.org/10.1007/s10068-012-0063-8.

38. Francis, F.J. Colorimetry of food. Bagley, E.B. (ed). AVI Publishing, Westport, UK. 1983; pp. 105-124.

39. Taoukis, P.S. Application of Time-Temperature Integrators for Monitoring and Management of Perishable Product Quality in the Cold Chain. In: Smart Packaging Technologies for Fast Moving Consumer Goods. Joseph Kerry, P.B. John Wiley \& Sons, Ltd: England. 2008; pp. 61-74.

40. Wu, D.; Hou, S.; Chen, J.; Sun, Y.; Ye, X.; Liu, D.; Meng, R.; Wang, Y. Development and characterization of an enzymatic time-temperature indicator (TTI) based on Aspergillus niger lipase. LWT-Food Sci. Technol. 2015, 60, 1100-1104, https://doi.org/10.1016/j.lwt.2014.10.011.

41. Jaiswal, R.K.; Mendiratta, S.K.; Talukder, S.; Soni, A.; Saini, B.L. Enzymatic time temperature indicators: A review. Pharm. Innov. J. 2018, 7, 643-647.

42. Zhang, Q.Q.; Han, Y.Q.; Cao, J.X.; Xu, X.L.; Zhou, G.H.; Zhang, W.Y. The spoilage of air-packaged broiler meat during storage at normal and fluctuating storage temperatures. Poultry Sci. 2012, 91, 208-214, https://doi.org/10.3382/ps.2011-01519.

43. Limbo, S.; Tori, L.; Sinelli, N.; Franzetti, L.; Casiraghi, E. Evaluation and redictive modeling of shelf life of minced beef stored in high-oxygen modified atmosphere packaging at different temperatures. Meat Sci. 2010, 84, 129-136, https://doi.org/10.1016/j.meatsci.2009.08.035.

44. Cárdenas, F.C.; Giannuzzi, L.; Zaritzky, N.E. Mathematical modelling of microbial growth in ground beef from Argentina. Effect of lactic acid addition, temperature and packaging film. Meat Sci. 2008, 79, 509-520, https://doi.org/10.1016/s0168-1605(97)00127-x.

45. Tsironi, T.; Ronnow, P.; Giannoglou, M.; Taoukis, P.S. Developing suitable smart TTI labels to match specific monitoring requirements: The case of Vibrio spp. growth during transportation of oysters. Food Control. 2017, 73, 51-56, https://doi.org/10.1016/j.foodcont.2016.06.041.

46. Tsironi, T.; Giannoglou, M.; Platakou, E.; Taoukis, P.S. Evaluation of Time Temperature Integrators for shelf-life monitoring of frozen seafood under real cold chain conditions. Food Packag. Shelf Life. 2016, 10, 46-53, https://doi.org/10.1016/j.fpsl.2016.09.004.

47. Brizio, A.P.D.R.; Prentice, C. Use of smart photochromic indicator for dynamic monitoring of the shelf life of chilled chicken based products. Meat Sci. 2014, 96, 1219-1226, https://doi.org/10.1016/j.meatsci.2013.11.006.

48. Ellouze, M.; Augustin, J.C. Applicability of biological time temperature integrators as quality and safety indicators for meat products. Int. J. Food Microbiol. 2010, 138, 119-129, https://doi.org/10.1016/j.ijfoodmicro.2009.12.012.

49. Vaikousi, H.I.; Biliaderis, C.G.; Koutsoumanis, K.P. Applicability of a microbial Time Temperature Indicator (TTI) for monitoring spoilage of modified atmosphere packed minced meat. Int. J. Food Microbiol. 
2019, 133, 272-278, https://doi.org/10.1016/j.ijfoodmicro.2009.05.030.

50. Tsironi, T.; Gogou, E.; Velliou, E.; Taoukis, P.S. Application and validation of the TTI based chill chain management system SMAS (Safety Monitoring and Assurance System) on shelf life optimization of vacuum packed chilled tuna. Int. J. Food Microbiol. 2009, 128, 108-115, https://doi.org/10.1016/j.ijfoodmicro.2008.07.025. 